\title{
STUDY OF FLUORIDE IN GROUNDWATER OF KHARGONE TOWN (M.P.) WITH REFERENCE TO IT'S IMPACT ON HUMAN HEALTH
}

\author{
Anita Solanki \\ B.L.P. Govt. P.G. College, Mhow, M.P, India
}

Article DOI: https://doi.org/10.36713/epra6081

\begin{abstract}
"Groundwater is the water present beneath Earth's surface in soil pore spaces and in the fractures of rock formations". The earth is full of natural resources needed for the development of mankind. The ground water is not suitable for drinking and other purposes. Generally the groundwater is considered least polluted as compared to surface water. Fluoride is a chemical element which is found in groundwater and has become one of the most important toxicological environmental hazards globally. High range of fluoride in drinking water it causes fluorosis disease. The fluoride condition were detected in ground water of khargone town. A large population of khargone town is using groundwater for drinking and domestic purposes.
\end{abstract}

KEYWORDS : Groundwater, Fluoride, Well, Tubewell, Handpump.

\section{INTRODUCTION}

Groundwater sources can become contaminated with chemicals as those used in fertilizers and pesticides and germs, Such as bacteria, viruses and parasites. We know very well that water plays an essential role in human life. Water is used for many purpose like drinking, cooking, bathing, washing and irrigation. Fluoride is mineral which is found naturally in the soil, rocks and water. Fluoride is beneficial for teeth. The permissible limit of fluoride is $1.0 \mathrm{mg} / \mathrm{l}$ by WHO and BIS. Above 1.0 $\mathrm{mg} / \mathrm{l}$ fluoride cause fluorosis disease in human body. Fluoride used in toothpaste to improve dental health care. Dental fluorosis may be an important complication of diabetes insipidus and demonstrate the possibility that excessive consumption of optimally fluoridated water can lead to sever development enamel defects (Seow and Thomsett 1994). A large population of khargone town is using groundwater for drinking purpose. This study is to know the fluoride level in groundwater and its suitability for drinking purpose at khargone town, M.P. for this object 6 groundwater sampling station were monitored during 2008 seasonally.

\section{MATERIAL AND METHOD}

Study Area : Khargone town was selected for the present study. It's a part of west Nimar zone.
Location : Khargone is district place of Madhya Pradesh. Khargone district lies between north latitudes $22^{\circ} 47^{\prime}$ and $22^{\circ} 35^{\prime}$ and east longitudes $75^{\circ}$ $19^{\prime}$ and $76^{\circ} 14^{\prime}$ in parts of survey of India.

Sampling stations : The 6 sampling stations were selected randomly in different area of khargone town. Which cover all the direction of the town. These sampling stations are combination of 2 handpump, 2 tubewell and 2 open well. All the sampling stations were monitored seasonally. Detail of sampling stations is as under:-
(a) Hand pumps colony
(b) Wells : (i) Brijvihar colony (ii) Krishiupaj mandi
(c) Tube wells : (i) Gouridham (ii) Jyoti nagar. Collection, observation :- water samples were collected from these stations and testing was done as per the standard methods described by APHA (1992). The data was collected seasonally i.e. Rainy, winter, and summer.

\section{RESULT AND DISCUSSION}

The result of fluoride level of groundwater is represented in table (1 to 3 ). It is an established fact that maintenance of healthy equatic system depends on minerals and physico - chemical properties of water. The fluoride value of Nutan nagr hand pump 
water was $0.03 \mathrm{mg} / \mathrm{l}$ in rainy season and $0.04 \mathrm{mg} / \mathrm{l}$ in winter season. In summer season it was dried due to high temperature. The variability in heterogeneous urban populations may be too high for the effect, if any of low level fluoride administration on skeletal tissues to be discerned (Charchra et al., 2010). Persons with renal failures can have a four fold increase in skeletal fluoride content are at more risk of spontaneous bone features and akin to skeletal fluorosis even at $1.0 \mathrm{ppm}$ fluoride in drinking water (Ayoob and Gupta 2006). The fluoride value of BTI colony hand pump water was $0.02 \mathrm{mg} / \mathrm{l}$ in rainy and $0.01 \mathrm{mg} / \mathrm{l}$ in winter season. The fluoride value of well water of Brijviahr colony and Krishi upaj mandi were nil (free from fluoride). The fluoride level of tubewell water of Gouridham was also nil. The fluoride level of tubewell water of Jyoti nagar was
$0.01 \mathrm{mg} / \mathrm{l}$ in rainy season and $0.01 \mathrm{mg} / 1$ in winter season. It was dried in summer season. The intake of elevated fluoride has a significant impact on human health; specially immediate problems that are seen in children's teeth (Narsimha and Rajitha 2018).

I observed higher value in rainy season. It may be in groundwater is because of natural or anthropogenic causes or a combination of both several rocks have fluoride bearing minerals. High fluoride concentration has lifelong health impacts ranged from loss of teeth to debilitaling pain (Demelash et.al., 2019). The weathering of these rocks and infiltration of rainfall through in increase fluoride concentration in groundwater consumption of water with fluoride concentration above $1.5 \mathrm{mg} / \mathrm{l}$ result in acute to chronic dental fluorosis (Brindha and Elango 2011).

Table - 1 : Fluoride level of water of handpumps.

\begin{tabular}{|c|c|c|c|}
\hline \multirow{2}{*}{ S.No. } & \multirow{2}{*}{ Season } & \multicolumn{2}{|c|}{ Stations } \\
\cline { 3 - 4 } & & Nutan nagar & BTI colony \\
\hline 1 & Rainy & 0.03 & 0.02 \\
\hline 2 & Winter & 0.02 & 0.01 \\
\hline 3 & Summer & Dried & Dried \\
\hline
\end{tabular}

Table - 2 : Fluoride level of water of Wells.

\begin{tabular}{|c|c|c|c|}
\hline \multirow{2}{*}{ S.No. } & \multirow{2}{*}{ Season } & \multicolumn{2}{|c|}{ Stations } \\
\cline { 3 - 4 } & & Brijvihar & Krishi upaj mandi \\
\hline 1 & Rainy & 0.00 & 0.00 \\
\hline 2 & Winter & 0.00 & 0.00 \\
\hline 3 & Summer & 0.00 & 0.00 \\
\hline
\end{tabular}

Table - 3 : Fluoride level of water of tubewells.

\begin{tabular}{|c|c|c|c|}
\hline \multirow{2}{*}{ S.No. } & \multirow{2}{*}{ Season } & \multicolumn{2}{|c|}{ Stations } \\
\cline { 3 - 4 } & & Gouridham & Jyoti nagar \\
\hline 1 & Rainy & 0.00 & 0.01 \\
\hline 2 & Winter & 0.00 & 0.01 \\
\hline 3 & Summer & 0.00 & Dried \\
\hline
\end{tabular}

\section{CONCLUSION}

The fluoride content of all the groundwater samples of present study were under the desirable limit of WHO and BIS i.e. $1.00-1.5 \mathrm{mg} / \mathrm{l}$. It is in agreement with the study of Dhakad and Choudhary (2004). We have to be use the clean water. Fluorided water sources should be avoid and go for other sources. We have to be treat the groundwater by insitu and exsitu treatment method like Distillation, Reverse osmosis, Activated alumina, Bone char carbon etc.

\section{REFERENCES}

1. Ayoob, S. and Gupta, A.K. fluoride in drinking water: A review on the status and stress effects. Critical Rev. in Env. Science and technology, 2006; 36: 433 - 487 .

2. Brindha, $K$. and Elango, L. fluoride in groundwater : causes, Implications and mitigation measures In : monoroy, S.D. (ED), fluoride properties, application and Env. Management, 2011; $111-136$.

3. Chachra, D; Limeback, H; Villet, TL; Grynpas, $M D$. The long term effects of water fluoridation on the human skeleton. Journal of dental research Nov. 2010; 89 (11): $1219-1223$.

4. Demelash, H., Beyene, A., Abebe, Z. etal. Fluoride concentration in ground water and 
prevalence of dental fluorosis in Ethiopian Rif velley: Systematic review and meta - analysis. BMC public health19, 1298 (2019). https://doi.org/10.1186/s12889-019-7646-8

5. Dhakad, NK and choudhary preeti. Monitoring of water pollution from refuse dump and septic tank system at dhar town of M.P. India J. Applied and pure bio, $2004 ; 19(3): 399-404$.

6. Narsimha, A . and Rajitha, S. spatial distribution and seasonal variation in fluoride enrichment in ground water and its associated human health risk assessment in telangana state, south India. Hum Ecol Risk Assess int J, 2018; 24(8) : 2119 2132.

7. Seow, W.K. and Thomsett, M.J. Dental fluorosis as a complication of hereditary diabetes insipedus : studies of six affected patients pediatr Dent. (1994); 16 (2); $128-132$. 